\title{
Why is bacterioplankton growth in coral reef framework cavities enhanced?
}

\author{
S. R. Scheffers ${ }^{1,2,3,4, *}$, R. P. M. Bak ${ }^{1,3}$, F. C. van Duyl ${ }^{1}$ \\ ${ }^{1}$ Royal Netherlands Institute for Sea Research (NIOZ), PO Box 59, 1790 AB Den Burg, Texel, The Netherlands \\ ${ }^{2}$ CARMABI Foundation, PO Box 2090, Willemstad, Curaçao, Netherlands Antilles \\ ${ }^{3}$ University of Amsterdam, IBED, PO Box 94766, 1090 GT Amsterdam, The Netherlands \\ ${ }^{4}$ Present address: University of Essen, Faculty of Biology and Geography, Universitätsstraße 5, 45141 Essen, Germany
}

\begin{abstract}
Abundance, growth rates and nutrient limitation of the heterotrophic bacteria present in the reef water column and reef cavity water were measured on a fringing reef at Curaçao (Netherlands Antilles). Bacterial in situ growth rates were measured using dialysis bags. Nutrient limitation was measured using bioassays with different amendments of inorganic nutrients (nitrate, ammonium, phosphate) and dissolved organic carbon (glucose). Cell sizes were measured in the reef water column and over an intra-cavity gradient inside reef cavities, from the cavity center to the wall of the cavity. Bacterial abundance was lower in cavities, while growth rates were on average 3.6 times higher than in open reef water. The bacterial community in open reef water was limited in its growth by all nutrients, in contrast to cavity water, in which bacteria were limited by phosphate. Cell volumes decreased significantly from open reef water towards the cavity wall. Results suggest that conditions in cavities have a positive effect on bacterial growth. Growth limitation by $\mathrm{N}$ is alleviated through enhanced mineralization in cavities. Through rapid exchange with the ambient water, cavities enrich the overlying reef water with inorganic $\mathrm{N}$.
\end{abstract}

KEY WORDS: DOC · DIP · DIN · Nutrient limitation · Growth rates · Heterotrophic bacteria • Cavities $\cdot$ Coral reef

\section{INTRODUCTION}

Most coral reefs occur in oligotrophic waters with low dissolved nutrient concentrations and low standing stocks of phyto- and bacterioplankton. During passage over the coral reef, water features change and obtain a reef signature often characterized by depleted phytoplankton and bacterioplankton concentrations and enhanced dissolved nutrient concentrations (e.g. Ayukai 1993, Yahel et al. 1998, Gast et al. 1999, van Duyl et al. 2002). Growth rates of heterotrophic bacterioplankton in coral reef overlying waters are usually enhanced the closer the bacteria get to the reef and the coral bottom (Moriarty et al. 1985, Gast et al. 1999, van Duyl \& Gast 2001). The highest growth rates have been reported for the coral surface microlayer (coral contact water) and coral mucus layer (Ducklow \& Mitchell
1979, Paul et al. 1986, van Duyl \& Gast 2001). Coral exudates are suitable food for the growth of heterotrophic bacterioplankton (Ferrier-Pagès et al. 2000). Besides a source of organic matter via benthic primary producers (corals and benthic algae), the reef bottom is a sink for particulate organic matter (e.g. plankton, detritus) and source of inorganic nutrients (Capone et al. 1992, Hatcher 1997, Rasheed et al. 2002). The benthic mineralization is fuelled by particulate organic matter settling on the bottom, by benthic microalgae (Heil et al. 2004), and by plankton trapped and mineralized by predominantly benthic heterotrophic suspension-feeding organisms, such as gorgonians, tunicates, and sponges (Buss \& Jackson 1981, Bak et al. 1998, Pile 1999, Fabricius \& Dommisse 2000, Wild et al. 2004). Hotspots for plankton depletion and mineralization on coral reefs are cryptic habitats, such as crevices 
and coral cavities (Richter et al. 2001, Scheffers et al. 2004). Despite high effluxes of ammonia and nitrate, inorganic nutrient concentrations usually remain low in the benthic boundary layer, due to efficient internal cycling and water exchange. Inorganic N and P concentrations in coral cavities are usually enhanced compared to concentrations on the coral reef bottom and in the overlying water (Gast et al. 1998, Richter et al. 2001). Bacterioplankton in the benthic boundary layer is confronted with these different gradients of nutrients, which can result in small-scale spatial variations in growth rates (van Duyl \& Gast 2001).

It is now well established that nitrogen and, in particular, phosphorus may limit growth of heterotrophic bacteria in marine waters (Elser et al. 1995, Pomeroy et al. 1995, Thingstad \& Rassoulzadegan 1995, Cotner et al. 1997, Thingstad et al. 1998, Sala et al. 2002). Bacteria acquire a significant fraction of their $\mathrm{N}$ and $\mathrm{P}$ demand via the uptake of inorganic forms of these elements (e.g. Kirchman 2000). Particularly in oligotrophic environments, inorganic nutrients are a potentially limiting factor for bacterial growth. The ability to take up inorganic nutrients places heterotrophic bacteria in direct competition with primary producers. Heterotrophic bacteria have $\mathrm{P}$ requirements that are typically 10 times higher than those of algae, whereas their $\mathrm{N}$ demand is not that different (Bratbak 1985, Vadstein et al. 1988, Lee \& Fuhrman 1987). Therefore, bacteria can be an important competitor for $\mathrm{P}$ with algae and a sink for phosphorus. Bacterioplankton may become P-limited in environments where dissolved organic carbon (DOC) and $\mathrm{N}$ are available. Metazoan grazing on bacteria and/or a poor ability to retain acquired $\mathrm{P}$ by bacterioplankton may alleviate bacterial $\mathrm{P}$ limitation (Vadstein et al. 2003). $\mathrm{N}$ and $\mathrm{C}$ limitation of bacterial growth appear to be less common, but also occur (Carlson et al. 2002, Sala et al. 2002). Bacterial growth in atoll lagoons appears to be primarily limited by inorganic $\mathrm{N}$, but organic $\mathrm{P}$ and DOC limitation were also observed (Torréton et al. 2000). Carbon incorporation ultimately determines the $\mathrm{N}$ and $\mathrm{P}$ demand of growing bacteria (Carlson et al. 2002).

We examined heterotrophic bacterial standing stocks, bacterial growth rates, and bacterial nutrient requirements (through macronutrient and DOC amendments in batch cultures) in 2 different water types: reef cavity water and reef water column. The aim of our study was to investigate if the growth rate in cavity water was enhanced com- pared to reef water and if the enhanced concentration of cavity inorganic nutrients contributes to the higher growth rate of reef cavity bacteria compared to reef water column bacteria.

\section{MATERIALS AND METHODS}

Study area. The framework cavities used in our study were located on the fringing reef of Curaçao, Netherlands Antilles ( $\left.12^{\circ} 12^{\prime} \mathrm{N}, 68^{\circ} 56^{\prime} \mathrm{W}\right)$. We studied 10 different cavities at a depth of approximately $15 \mathrm{~m}$ (Fig. 1) on the reef slope at CARMABI Buoy Zero/Buoy One (van Duyl 1985). The cavities were scattered over $200 \mathrm{~m}$ along the coastline. The cavities were comparable in their biotic and physical characteristics to those described by Scheffers et al. $(2003,2004)$. The selected cavities had volumes of approximately 100 l, solid carbonate walls, and a sandy bottom. The main opening of the cavities was directed off the reef slope, and the hard surface area was covered (>60\%) with sessile suspension feeders, such as sponges, polychaetes, bivalves, and tunicates. Cavity water is designated in this study as the body of water in a cavity. All cavity water samples were taken from the center of a cavity. Open reef water was sampled directly in front of a cavity opening, $1 \mathrm{~m}$ away from the substrate. Reef water was sampled before cavity water to avoid disturbance of the water properties. Sampling took place between 10:00 and 14:00 h. The samples were kept cold in the dark until processing. Growth rate experi-

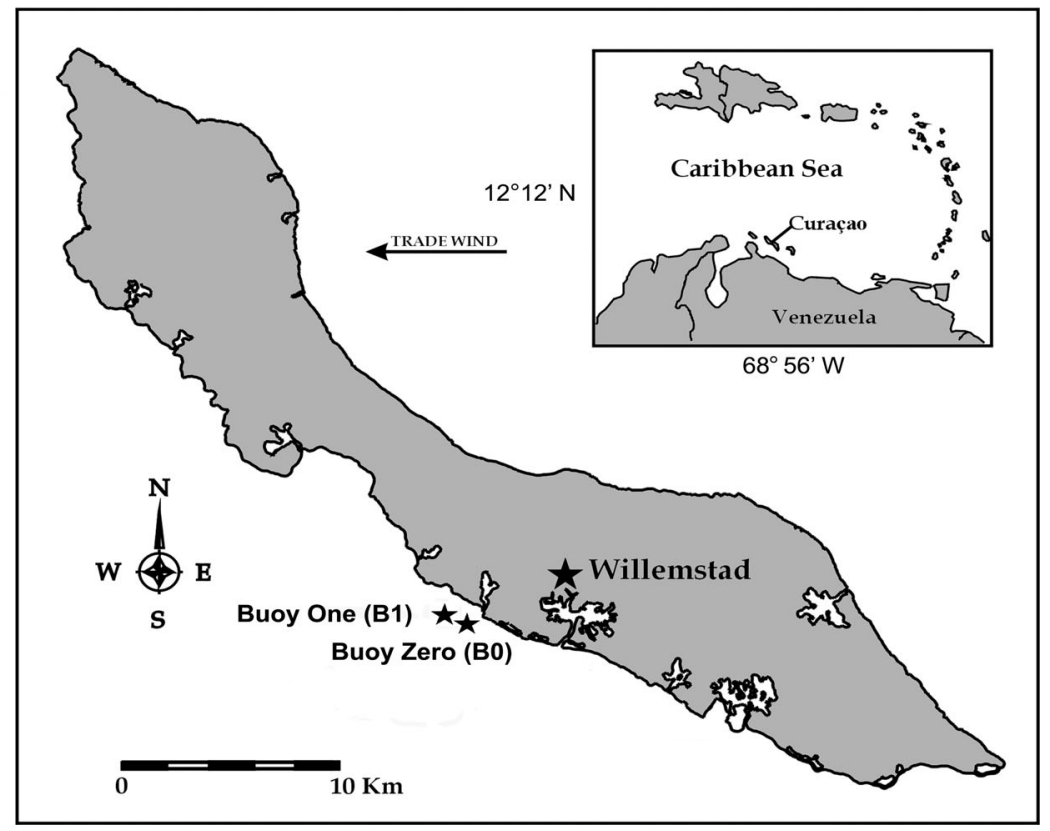

Fig. 1. Map of Curaçao with the localities of the experiments, Carmabi house reefs Buoy Zero (B0) and Buoy One (B1) 
ments were performed in November 2000; bioassay experiments were performed in December 2000.

Bacterial abundance. Samples $(10 \mathrm{ml})$ taken to obtain heterotrophic bacterial concentration, were fixed with $0.2 \mu \mathrm{m}$ filtered and buffered (sodium tetraborate, $\mathrm{pH}=7.9$ ) formaldehyde (final concentration: $0.7 \%)$. In the laboratory, the samples were stained with acridine orange and subsequently filtered (0.03 bar underpressure) onto $25 \mathrm{~mm}, 0.2 \mu \mathrm{m}$ polycarbonate filters (Nuclepore) supported by a $0.45 \mu \mathrm{m}$ cellulose acetate filter, within $24 \mathrm{~h}$ after sampling (Hobbie et al. 1977). The filters were mounted on slides in nonfluorescent immersion oil (Olympus). The microscopic slides were then stored in a freezer $\left(-20^{\circ} \mathrm{C}\right)$. Bacteria were counted and sized with a Zeiss Axiophot epifluorescence microscope (1250× magnification). We used a grid of $36 \times 36 \mu \mathrm{m}$, divided in 10 rows and 10 columns, for counting and sizing bacteria. At least 10 random grids per filter and at least 200 cells were counted.

Bacterial growth rates. Bacterial growth rate measurements were performed with dialysis bags (Spectrapor 4 dialysis membranes 12000 to $14000 \mathrm{MWCO}$ ) of $100 \mathrm{ml}$ (Herndl 1993). Before use, the dialysis bags were pre-soaked in $0.2 \mu \mathrm{m}$ filtered seawater for $1 \mathrm{~h}$. Since all molecules $<14 \mathrm{kD}$ can pass the membrane, a steady supply of in situ nutrients and DOC was secured. In a previous study (Ferrier-Pagès \& Gattuso 1998), cellulose dialysis membranes proved to be sufficiently permeable to inorganic and organic nutrients (diffusive exchange of $<1 \mathrm{~h}$ ) and had no effect (negative or positive) on plankton growth rates. Water samples were taken in situ (inside and in front of the cavities) in $750 \mathrm{ml}$ syringes and immediately brought to the boat at the surface, where the sampled water was filtered (0.03 bar underpressure). Duplicate dialysis bags were filled with $0.8 \mu \mathrm{m}$ filtered cavity or reef water. Subsequently, dialysis bags were attached to frames and placed on the spot where the sample water originated (1 frame in the cavity and 1 just outside). Samples were taken with $10 \mathrm{ml}$ syringes through a specially designed cap at $T=0$, at $T=$ $8 \mathrm{~h}$, and at $T=24 \mathrm{~h}$. Samples were then brought to the laboratory on ice and in the dark for bacterial counting. Experiments were conducted in 10 different cavities. Bacterial abundance at $T=0$ and at $T=24 \mathrm{~h}$, and the doubling times of bacteria in dialysis bags were compared between reef and cavity waters.

Cell volume gradients within the cavity were obtained using a Plexiglas ruler ( 25 to $50 \mathrm{~cm}$ length, dependent on cavity size) on which 3 , equally dis- tanced, $10 \mathrm{ml}$ syringes were attached. The plungers could be pulled out simultaneously. The actual positions of the syringes were in the center of the cavity, close to the cavity wall ( $5 \mathrm{~cm}$ away), and midway inbetween. A reef water sample was taken before the cavity water samples. A total of 10 different cavities were sampled, 200 bacteria per sample were sized, totaling 8000 bacteria. The mean cell volume of heterotrophic bacteria was calculated by measuring the length $(l)$ and width $(w)$ of cells and assuming cells to be cylindrical, with a hemisphere of diameter $w$ at each end:

$$
\text { volume }=\pi / 4\left(w^{2}\right)(1-w / 3)
$$

Bioassays. To investigate nutrient limitation of bacterioplankton growth in reef and cavity waters, we conducted a series of controlled enrichment experiments with cavity and reef waters. We focused on the inorganic macronutrients $\mathrm{N}$ (nitrate and ammonium) and $\mathrm{P}$ (orthophosphate), and on DOC. Bioassay water was collected in situ with $750 \mathrm{ml}$ syringes and brought to the laboratory, in darkness, for treatment. The cavity water samples from 10 different cavities were gently mixed and filtered ( 0.03 bar underpressure) over a pre-rinsed $0.8 \mu \mathrm{m}$ polycarbonate (Millepore) filter to reduce grazing activity. Most of the heterotrophic bacteria ( 0.2 to $0.4 \mu \mathrm{m}$ diameter) will pass this filter. After filtration, the water was poured into duplicate $1 \mathrm{l}$, acid- and distilledwater-washed, PC bottles. Reef water samples were treated in the same way. Each set of bottles (duplicates) received the amendments summarized in Table 1 . We used a total of 36 bottles for the experiment $(9 \times 2$ for reef water and $9 \times 2$ for cavity water).

The racks with bottles were covered with light impermeable foil and put back in the sea to be subjected

Table 1. Overview of the nutrient amendments 
to natural, in situ, temperature (ca. $27^{\circ} \mathrm{C}$ ). Heterotrophic bacteria abundance was counted $8 \mathrm{~h}$ after the start of the experiment and subsequently every $8 \mathrm{~h}$ for $64 \mathrm{~h}$. Data are presented as percent change in bacterial abundance relative to the control.

\section{RESULTS}

\section{Bacterial abundance and growth rates}

Bacterial abundance at $T=0$ in the dialysis bags was significantly lower in cavity water than in reef water ( $t$-test for paired comparisons: $t=5.4 ; \mathrm{p}<0.05$ ), indicating that most experiments with cavity water started off with a lower bacterial abundance (Fig. 2a). Bacterial abundance ranged from $2.9 \times 10^{5}$ to $5.9 \times 10^{5}$ cells ml $^{-1}$ in cavity water and from $4.4 \times 10^{5}$ to $6.2 \times 10^{5}$ cells ml $^{-1}$ in reef water. Cavity water bacterial abundance was more variable than reef water bacterial abundance. After $24 \mathrm{~h}$ of incubation in dialysis bags, bacterial abundance was significantly higher in cavities than in reef water ( $t$-test for paired comparisons: $t=4.1$; $\mathrm{p}<$ 0.001), indicating that most experiments with cavity water reached a higher bacterial abundance (in 9 of 10 experiments) after $24 \mathrm{~h}$ of incubation (Fig. 2b). Bacterial abundances at $T=24 \mathrm{~h}$ ranged from $5.1 \times 10^{5}$ to $20.4 \times 10^{5}$ cells ml ${ }^{-1}$ in cavity water and from $4.7 \times 10^{5}$ to $9.7 \times 10^{5}$ cells $\mathrm{ml}^{-1}$ in reef water (Fig. $2 \mathrm{~b}$ ).

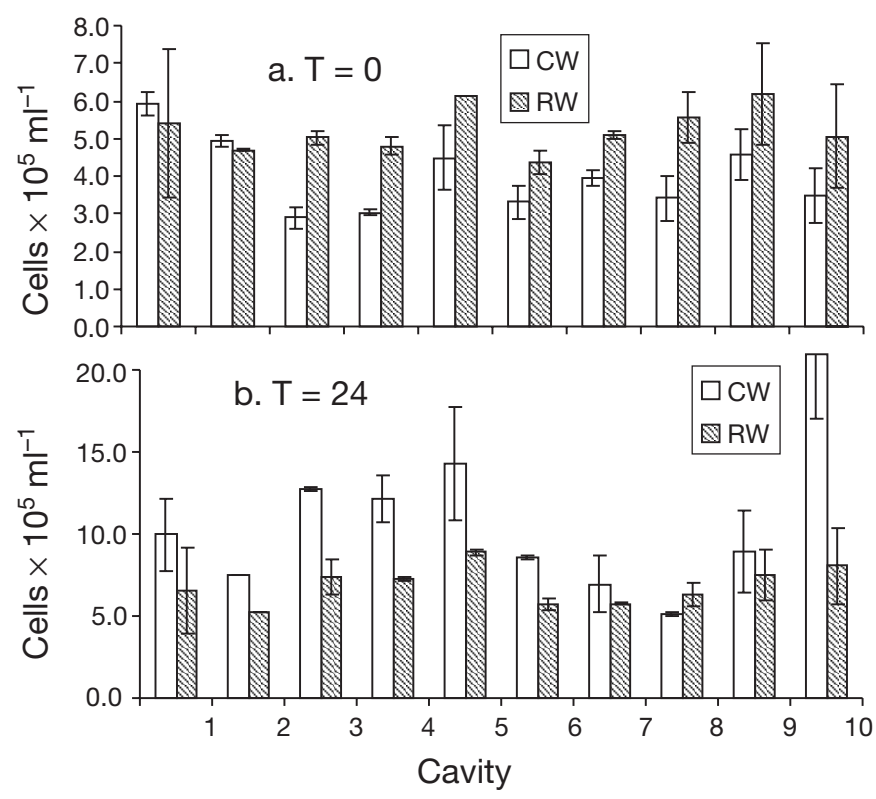

Fig. 2. Comparison of bacterial abundance in reef water (RW) and cavity water $(\mathrm{CW})(\mathrm{a})$ at the start $(T=0)$ and (b) end $(T=24)$ of the dialysis bag experiments $(\mathrm{n}=10)$. Cavity numbers 1 to 5 at B0 and 6 to 10 at B1 (averages of 2 replicates with standard deviations). Note the difference in scales of the $y$-axes
Doubling times of bacteria exposed to cavity water were significantly shorter (on average 3.6 times shorter) than doubling times of bacteria exposed to reef water ( $t$-test for paired comparisons: $t=7.9$; $\mathrm{p}<0.05$ ). The average doubling time of reef water bacteria was $82 \mathrm{~h}$ and ranged from 36 to $149 \mathrm{~h}$; cavity water bacteria showed an average doubling time of $24 \mathrm{~h}$ and a range of from 10 to $44 \mathrm{~h}$ (Fig. 3). The doubling times of cavity and reef water bacteria exhibited high spatial and temporal variability, whereby the doubling time variability of cavities was lower than that of reef water.

Plotting doubling times of cavity bacteria versus doubling times of reef bacteria shows that the latter significantly (1-sample $t$-test: $\mathrm{R}=0.93 ; \mathrm{p}<0.0001$ ) increases with the increasing doubling times of cavity water bacteria (Fig. 4).

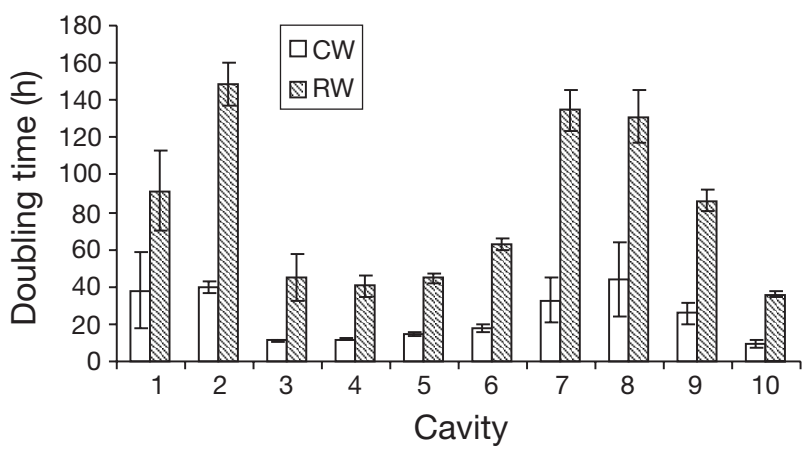

Fig. 3. Doubling times reef water bacteria (RW) and cavity water bacteria (CW) of 10 different cavities. Cavity numbers 1 to 5 at B0 and 6 to 10 at B1 (averages of 2 replicates with standard deviations)

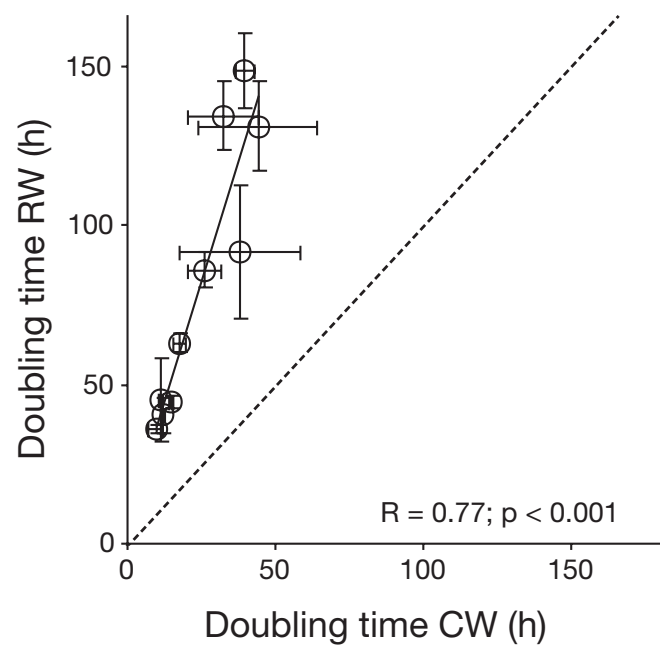

Fig. 4. Relation between the doubling times of cavity water bacteria (CW) and those of reef water bacteria (RW). Continuous line is a linear regression fit with $R=0.77(p<0.001$, averages of 2 replicates with standard deviations). Dashed line represents the line along which bacterial doubling times in reef water are the same as those in cavity water 


\section{Bioassays}

The bioassay data (Fig. 5) show that there were response differences to amendments of inorganic nutrients and DOC between incubations of cavity and reef water bacteria. Bacterial growth in reef water and cavity water samples was not different without amendment (control, Fig. 5a). The heterotrophic bacteria within the cavity water samples have a potentially higher specific growth rate and/or reach a higher level when $+\mathrm{P}$ (Fig. 5c), a combination of $+\mathrm{N}+\mathrm{P}$ (Fig. 5h), and $+\mathrm{N}+\mathrm{P}+\mathrm{C}$ (Fig. 5i) are added, compared to the control. On the other hand, $+\mathrm{N}$ (Fig. 5b), $+\mathrm{C}$ (Fig. 5d), a combination of $+\mathrm{N}+\mathrm{C}$ (Fig. 5e), and $+\mathrm{NH}$ (Fig. 5f) additions showed no clear stimulation in bacterial growth rates in cavity water compared to the control. Reef water bacteria show a positive response in growth to all amendments. Addition of $+\mathrm{P}$ (Fig. 5c), $+\mathrm{P}+\mathrm{C}$ (Fig. 5g), and $+\mathrm{N}+\mathrm{P}+\mathrm{C}$ (Fig. 5i) had the same quantitative effect on bacterial growth in both water types. The amendment of $+\mathrm{N}$ and $+\mathrm{NH}$ (Fig. $5 b \&$ f) to reef water incubations showed the sole clear difference in response between reef water and cavity water bacteria. The addition to both water types of a combination of $+\mathrm{N}+\mathrm{P}+\mathrm{C}$ resulted in the highest abundance of heterotrophic bacteria $\left(\sim 9 \times 10^{6}\right.$ cells $\left.\mathrm{ml}^{-1}\right)$.

\section{Cell volume and concentration gradient}

Heterotrophic bacterial cell characteristics were different for different water types (Fig. 6), with cell abundance (Fig. 6a) and volume (Fig. 6b \& c) decreasing into the cavity and towards the cavity wall, covered with cryptic suspension feeders. Reef water contained significantly larger cells then cavity water (1-sample $t$-test: $t=3.58 ; \mathrm{p}<0.001)$. Within the cavity, cell volumes significantly declined from the center of the cavity towards the cavity wall (1-sample $t$-test: $t=16.7$; $\mathrm{p}<0.001)$. The range in cell volume was largest in reef water and smallest in water close to the cavity wall. Mean bacterial cell volume in reef water

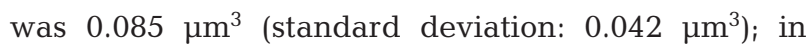

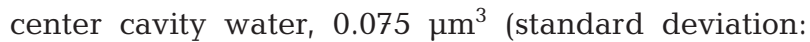
$0.028 \mathrm{\mu m}^{3}$ ); mid-way towards the cavity wall, $0.059 \mu^{3}$ (standard deviation: $0.023 \mu^{3}$ ); and in wall cavity water, $0.037 \mu^{3}$ (standard deviation: $0.015 \mu^{3}$ ). Cell concentration showed a similar pattern with bacterial abundance, decreasing from reef water towards the cavity wall (Fig. 6a). Size-frequency distributions (Fig. 6c) show that only the smaller cell size classes $\left(<0.08 \mu^{3}\right)$ of the bacterial community were still present in the cavity water close to the cavity wall and that size classes $>0.08 \mu^{3}$ were absent in the cavity wall samples. It is possible that the volume of individual cells was slightly under- or overestimated, depending on the degree of fluorescence of sized cells, but it is unlikely that the change in size of bacteria from the center towards the cavity wall is due to this purported artifact, which occurs at random.

\section{DISCUSSION}

We found large differences in bacterial abundance and doubling times between reef and cavity waters over small spatial scales (10 to $100 \mathrm{~cm}$ ). The bacterial abundance in cavity water is significantly lower than that in reef water, which is in agreement with Gast et al. (1998), who found a similar pattern of lower concentrations in crevice water compared to reef water on the terrace between 6 and $8 \mathrm{~m}$ depth. The abundance of bacteria in reef water (ca. $5.3 \times 10^{5}$ bacteria $\mathrm{ml}^{-1}$ ) is within the range generally found in coral reef waters (3.0 to $9.0 \times 10^{5}$ bacteria $\mathrm{ml}^{-1}$; see e.g. Moriarty et al. 1985, Ayukai 1993, Bak et al. 1998, Gast et al. 1998). The consumption of heterotrophic bacteria by suspension-feeding cryptofauna with fluxes of up to $49 \mathrm{mg}$ bacterial $\mathrm{C} \mathrm{m}^{-2}$ cavity surface area $\mathrm{d}^{-1}$ (Scheffers et al. 2004), accounts for lower bacterial concentrations in cavity water.

Our data show a significant difference between the bacterial doubling times in cavity water and those in reef water, with cavity water bacteria doubling times being on average 3.6 times shorter than the doubling times in reef water. Doubling times in reef water (on average $82 \mathrm{~h}$ ) were comparable to doubling times in reef water as measured by ${ }^{3} \mathrm{H}$-leucine incorporation at the same site by Gast et al. (1998), who found bacterial doubling times of ca. $80 \mathrm{~h}$ in reef water and slightly shorter doubling times (on average $75 \mathrm{~h}$ ) in small crevices with volumes of $<1$ up to several liters. Our average cavity bacteria doubling times (ca. $24 \mathrm{~h}$ ) were considerably shorter, but were in the same range as those found in the literature for coral reef waters. Ferrier-Pagès \& Gattuso (1998) report doubling times of 6 to $24 \mathrm{~h}$ in Bora Bay, Japan; Moriarty et al. (1990) report doubling times of 6 to $8 \mathrm{~h}$ in the Bay of Carpentaria, Australia; and Landry et al. (1984) present doubling times of 13 to $20 \mathrm{~h}$ in Kaneohe Bay, Hawaii. The initial bacterial abundance was significantly lower in cavity water than in reef water. This may have enhanced the growth rate in dialysis bags with cavity water (more food for rapid growth of bacteria). However, the total abundance of bacteria was, after $24 \mathrm{~h}$ of incubation, higher in cavity water bags than in reef water bags, indicating that there was more potential for formation of bacteria in cavity water than in reef water. This suggests that bacteria were supplied with extra nutrients (dissolved organic matter, inorganic 

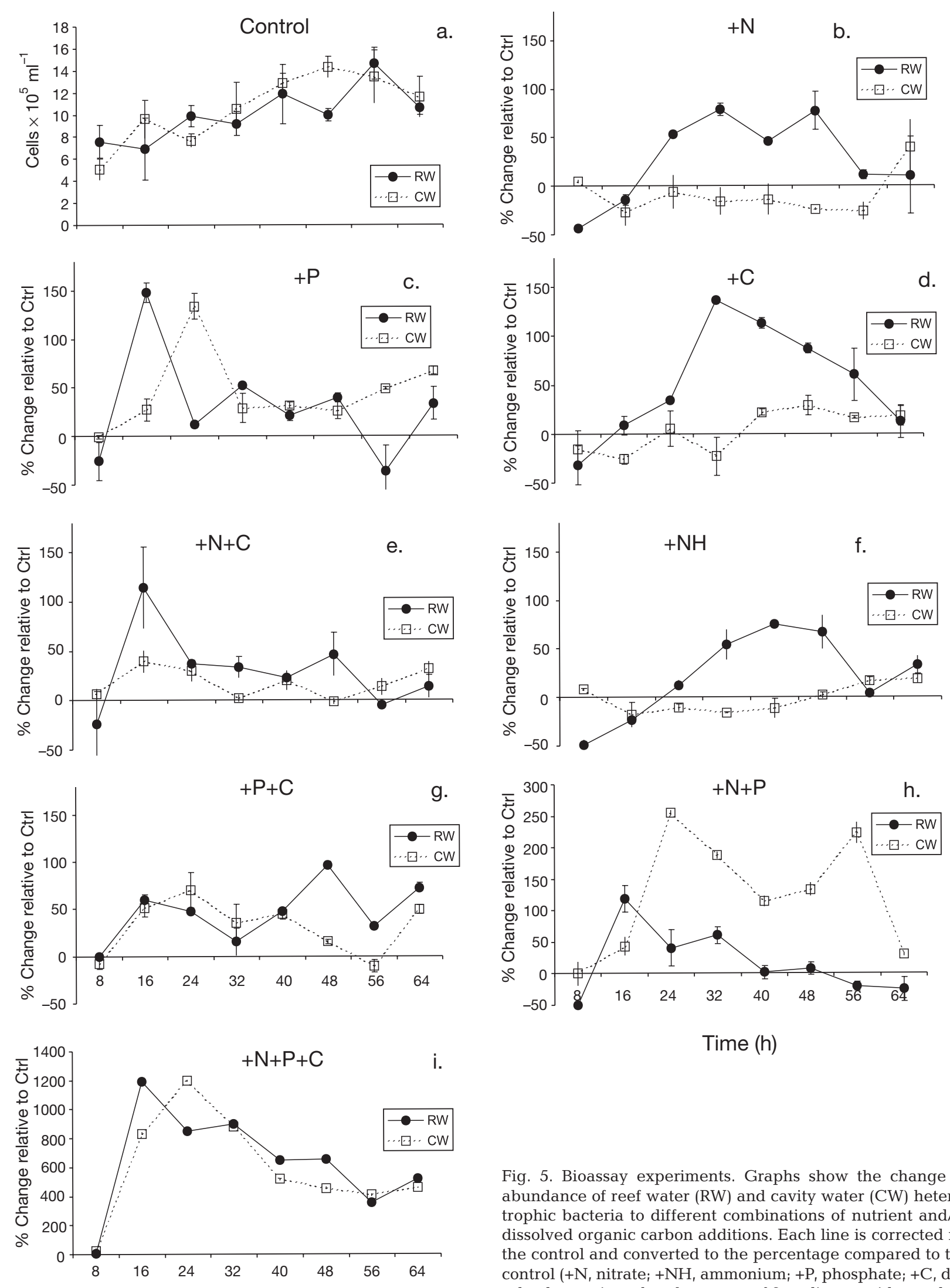

Time (h)

Fig. 5. Bioassay experiments. Graphs show the change in abundance of reef water (RW) and cavity water (CW) heterotrophic bacteria to different combinations of nutrient and/or dissolved organic carbon additions. Each line is corrected for the control and converted to the percentage compared to the control $(+\mathrm{N}$, nitrate $;+\mathrm{NH}$, ammonium $;+\mathrm{P}$, phosphate $;+\mathrm{C}$, dissolved organic carbon [averages of 2 replicates with standard deviations]) 

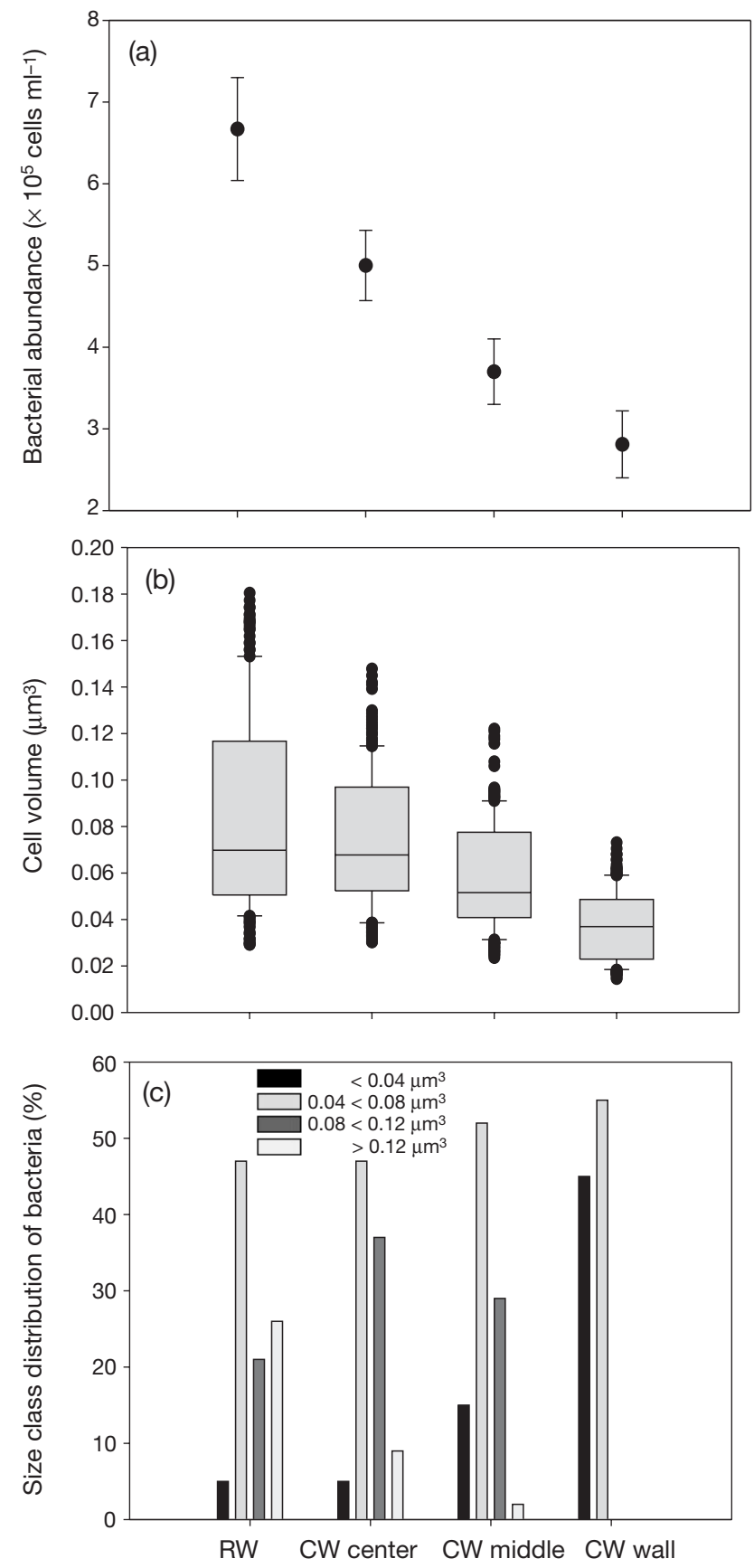

Fig. 6. Changes in (a) bacterial abundance, (b) biovolume, and (c) biovolume frequency distribution of the bacterial community from reef water towards cavity water close to the cavity wall (RW, reef water bacteria $[\mathrm{n}=2000]$; $\mathrm{CW}$ center, bacteria from water of the center of a cavity $[\mathrm{n}=2000]$; CW middle, bacteria from water mid-way between $\mathrm{CW}$ center and $\mathrm{CW}$ wall [ $\mathrm{n}=2000]$; CW wall, bacteria close to the wall of a cavity [ $\mathrm{n}=2000]$ ). Boxes in (b) show median $\pm 25 \%$ ranges, whiskers indicate 10 and $90 \%$, circles are outliers outside the 10th and 90th percentiles. Note: bacterial volumes might deviate from real, absolute volumes. This is due to the methods applied, which may either over- or underestimate cell volumes depending on the degree of fluorescence of individual cells nutrients) in cavity water. So the bacterioplankton in dialysis bags are continuously exposed to this water and apparently grow faster than bacterioplankton in dialysis bags in open reef water, where inorganic nutrients released from cavities are rapidly diluted. In the real reef situation, bacteria, which are exposed to cavity water during the short residence in cavities, will grow somewhat faster than bacteria outside cavities. The ecological significance is that the specific growth rates of bacteria in the benthic boundary layer (BBL) water are slightly higher than those of bacteria further away from the bottom.

Cell volumes of bacterioplankton in cavity water were, on average, smaller than the cell volumes in reef water, due to selective removal of larger cells by suspension-feeding cryptofauna in coral cavities. Smaller cells do have a higher affinity for nutrients (Button \& Robertson 2000). This may suggest that cavity water bacteria are limited to a lesser extent by very low natural nutrient concentrations than the larger reef water bacteria. This may have contributed to the shorter doubling times of bacterioplankton in cavity water than in reef water and to the higher abundance of bacteria in cavity water than in reef water after $24 \mathrm{~h}$ of incubation in dialysis bags. Taking all these aspects into account, we conclude that cavity water bears a more favorable signature for bacterial growth, in terms of higher nutrient availability, than reef water.

The positive relation between the doubling times of reef water bacteria and those of cavity water bacteria suggest that an exchange exists between these 2 water types affecting the bacterioplankton dynamics. It is widely recognized that water exchange is required for advecting food to the cryptic biota of coral cavities, which is critical for their survival (e.g. Buss \& Jackson 1981). Water exchange rates of coral cavities have been reported to be quite high, with water residence time in cavities of 4 to $5 \mathrm{~min}$ on average (Richter et al. 2001, van Duyl et al. in press). This high water exchange implies that cavity water favorable (in terms of higher nutrient availability) to bacterial growth is rapidly mixed with reef water, giving reef water a distinct signature. Such an effect is diminished with increasing distance from the cavity and reef bottom (van Duyl \& Gast 2001). The continuous release of water from the cavities, which is enriched in nutrients and depleted in bacterial abundance, contributes to the enhancement of bacterial growth in the overlying reef water and, thus, to the enhanced turnover of matter in reef ambient water. Nutrients are released by cryptic biota and efficiently sequestered by, e.g., bacterioplankton, which is subsequently removed again by cryptic suspension feeders. This process is important for the understanding of nutrient cycles in the reef ecosystem, particularly because cryptic habitats with 
cryptofauna represent a substantial part of the living surface on reefs (Richter et al. 2001, Scheffers et al. 2003). Besides nutrient release from coral cavities, nutrient release from sediments and, e.g., exudateand mucus-producing corals also exert an influence on reef water column characteristics (Ferrier-Pagès et al. 2000, Rasheed et al. 2002, Wild et al. 2004).

Cavities are net sources of inorganic nutrients on coral reefs (Richter et al. 2001, Scheffers et al. 2004). Inorganic nutrient concentrations (e.g. $\mathrm{NO}_{\mathrm{x}}, \mathrm{PO}_{4}$ ) are usually higher in cavities and crevices than in reef overlying water (Gast et al. 1998, Richter et al. 2001). At the study site van Duyl \& Gast (2001) and van Duyl et al. (in press) recorded DIN (dissolved inorganic nitrogen) concentrations that were, in most cases, higher in crevices ( 0.6 to $1.8 \mu \mathrm{M})$ than in the reef water in front of crevices ( 0.5 to $0.9 \mu \mathrm{M})$; the same pattern, but less predictable, was found for inorganic $\mathrm{P}$ (in crevices: 0.05 to $0.1 \mu \mathrm{M}$; in reef water: 0.02 to $0.04 \mu \mathrm{M}$ ). Regeneration of inorganic nutrients in cavities can be relatively rapid. Scheffers et al. (2004) have reported a net mean DIN release rate from cavities at the same study site in Curaçao of $0.67 \mathrm{mmol} \mathrm{m}^{-2}$ cavity inner surface $\mathrm{d}^{-1}$. For DIP (dissolved inorganic phosphorus), they did not establish a significant release from cavities. But net effluxes of DIP from cavities have been established (Richter et al. 2001, van Duyl et al. in press). These fluxes suggest that inorganic nutrient limitation may be alleviated in cavities, which could lead to the enhancement of bacterial growth in cavity water.

It is widely acknowledged that bacteria take up inorganic nutrients at low concentrations (Kirchman 2000). The ecological significance of this capacity has been recognized, and the mechanism is incorporated into models of nutrient and carbon flow in aquatic ecosystems (Bratbak \& Thingstad 1985, Thingstad 1987). However, empirical evidence of spatial and temporal variability in nutrient limitation of bacterial growth in oligotrophic coral reef waters is still rare. Limitation of bacterial growth by nitrogen or phosphorus presumably occurs as a consequence of the utilization of substrates that have high $\mathrm{C}: \mathrm{N}$ or $\mathrm{C}: \mathrm{P}$ values (Goldman et al. 1987, Goldman \& Dennett 1991, 2000). It has been suggested that labile organic carbon compounds may accumulate under these conditions and that these carbon sources are taken up rapidly and metabolized when the growth-limiting element becomes available (Cotner et al. 1997).

Our bioassay results show that inorganic $\mathrm{N}$ and $\mathrm{P}$ are potentially limiting factors in bacterial growth on reefs. Cavity water bacteria show a response of the community to enrichment with phosphate. The experiments with reef water bacteria indicate that the growth of the bacterial community is limited by all macronutrients
(N, P, and organic C). Our bioassays show that cavity water bacteria are phosphate-limited, despite the fact that DIP concentration in crevices is usually enhanced compared to the overlying water (van Duyl \& Gast 2001). A relatively high bacterial demand for $P$ could explain the $\mathrm{P}$ limitation of cavity bacteria. Some studies describe inorganic $\mathrm{N}$, instead of $\mathrm{P}$, as the predominant growth-limiting factor of bacteria in coral reef waters (e.g. Torréton et al. 2000). We found that after P alleviation, inorganic $\mathrm{N}$ is the limiting factor for bacterial growth in cavity water bioassays. After $\mathrm{P}$ and $\mathrm{N}$ addition the bacterial abundance in cavity water bioassays exceeded the abundance of bacteria in reef water bioassays, suggesting that there was more potential for cell production in cavity water than in reef water. This was also found within the dialysis bag experiments. Whether this was due to more labile DOC in cavity water than in reef water cannot be concluded, since we did not assess bacterial biomass or bacterial respiration. Nitrogen is the only amendment in cavity water, which did not show an increase in bacterial abundance relative to the control. Neither nitrate nor ammonia amendments stimulated bacterial production, suggesting that $\mathrm{N}$ is not the primary limiting factor for bacterial growth in cavity water. Mineralization in cavities apparently provides the bacterioplankton with sufficient inorganic $\mathrm{N}$ to alleviate $\mathrm{N}$ limitation. This $\mathrm{N}$ supply is predominantly in the form of nitrate (Scheffers et al. 2004), which needs to be reduced before uptake. Nitrate and ammonia amendments rendered, however, comparable results in reef and cavity water bioassays.

Besides $\mathrm{N}$ and $\mathrm{P}$, reef water bacteria appear to be predominantly DOC-limited. Bacterial abundance in reef water increased considerably after DOC amendments. Also, after addition of inorganic nutrients, reef water bacterial abundance shows an increase. The most likely explanation of this increase in bacterial abundance in water with amendments is that subcommunities within the reef water community react differently to different additions. Fonnes Flaten et al. (2003) suggest that in bioassay experiments with whole bacterial communities not all sub-communities react the same to nutrient and DOC amendments. Carlson \& Ducklow (1996) showed DOC limitation of heterotrophic bacteria in the Sargasso Sea. Others have found that the addition of labile carbon together with inorganic nutrients can stimulate bacterial production more than the sole addition of labile carbon (Cotner et al. 1997 Shiah et al. 1998, Thingstad et al. 1998, Carlson et al. 2002), indicating that energy and nutrient limitation can co-exist. We found comparable results for bacterial abundance increase when $\mathrm{N}, \mathrm{P}$, and $\mathrm{C}$ were added at the same time in both crevice water and reef water. The results show a smaller in- 
crease in bacterial abundance in reef water with only carbon amendment, indicating that once the energy requirement was alleviated a secondary limitation was evoked. Del Giorgio \& Cole (1998) discussed the possibility that bacteria maximize their rate of carbon catabolism of available $\mathrm{C}$, even when inorganic nutrients are not available. The potential advantage of this strategy of maintaining high electrochemical potentials across bacterial cell membranes is to support active transport functions and motility. Both of these functions would leave cells balanced to exploit transient increases in nutrients associated with the patchy nutrient distributions present in Curaçao reef water (Del Giorgio \& Cole 1998, Gast et al. 1998).

All experiments were performed under grazerreduced/excluded conditions. Nanograzers can recycle nutrients required by bacterioplankton (Strom 2000), but grazing of bacteria by nanoflagellates is insignificant, and nanoflagellate numbers in Curaçao reef water are low (Gast et al. 1999). If there were an effect of grazing by nanoflagellates on bacterial numbers and growth, it may only be discernable after $>50 \mathrm{~h}$ of incubation (Wilcox \& Fuhrman 1994). Our bioassay experiments were run for only $2.5 \mathrm{~d}$, and the conclusions are based on processes occurring within the first $50 \mathrm{~h}$. We assumed that the chemical form of these recycled nutrients and the $\mathrm{N}$-containing products of sponge excretion are similar to those used in the experimental amendments. However, we cannot rule out the possibility that compounds (e.g. DON, DOP) other than $\mathrm{NH}_{4}, \mathrm{NO}_{3}$, and $\mathrm{PO}_{4}$ in material released by grazers facilitate the utilization of otherwise unpalatable dissolved organic matter. Viral induced lysis of bacteria can have an effect on growth rates of susceptible bacteria; however, the literature shows that the overall bacterial density need not be affected (Middelboe et al. 2001). If a degree of bacteriophagy by marine viruses occurs, it would occur in all our experiments and tend to be evened out in our comparisons of the 2 different water types.

We conclude from the bioassay experiments that: (1) Bacterioplankton growth in coral cavity water is enhanced by alleviation of inorganic $\mathrm{N}$ limitation. (2) Cavity water bacteria communities are primarily P-limited. After alleviation of P limitation, $\mathrm{N}$ was the limiting nutrient. (3) The bacterial community in reef water is limited by the macronutrients $\mathrm{N}, \mathrm{P}$, and $\mathrm{C}$.

Because the bacterial growth rates in reef water and cavity water are tightly coupled, we argue that the $\mathrm{C} / \mathrm{N} / \mathrm{P}$-limited reef water bacterial community increases its specific growth rate during passage through coral cavities. Bacteria exposed to cavity water grow faster than bacteria exposed to reef water. This implies that bacteria, while present in regenerative spaces (cavities), grow faster than open reef water bacterioplankton.
In conclusion, our experiments show different responses of heterotrophic bacterial growth to characteristics of reef water column and reef cavity water. Specific bacterial growth is enhanced during its short residence in cavities through alleviation of $\mathrm{N}$ limitation. Our bioassays show that reef water bacteria are limited by dissolved organic carbon, inorganic nitrogen, and phosphorus, whereas bacterioplankton in cavity water primarily lack phosphorus. In view of the rapid exchange rate of cavities with the overlying reef water, our study supports the hypothesis that cavities play an important role in the enhancement of growth of the bacterioplankton that pass over coral reefs.

Acknowledgements. We wish to thank the staff of the CARMABI Foundation (Curaçao, Netherlands Antilles) and especially 'Don' Carlos Winterdaal and Brian Leysner for their cooperation. Gerard Nieuwland (NIOZ) and Arjen Kop (NIOZ) are thanked for their logistic support in the Netherlands and in Curaçao. Very special thanks go to Anja Scheffers for her assistance in the field. The critical comments of the reviewers contributed to further improvement of the manuscript. This study was financed by the WOTRO (Netherlands Foundation for the Advancement of Tropical Research) Grant No. W84-439.

\section{LITERATURE CITED}

Ayukai T (1993) Temporal variability of the nutrient environment on Davies Reef in the Central Great Barrier Reef, Australia. Pac Sci 47:171-179

Bak RPM, Joenje M, de Jong I, Lambrechts DYM, Nieuwland G (1998) Bacterial suspension feeding by coral reef benthic organisms. Mar Ecol Prog Ser 175:285-288

Bratbak G (1985) Bacterial biovolume and biomass estimations. Appl Environ Microbiol 49:1488-1493

Bratbak G, Thingstad TF (1985) Phytoplankton-bacteria interactions: an apparent paradox? Analysis of a model system with both competition and commensalism. Mar Ecol Prog Ser 25:23-30

Buss L, Jackson J (1981) Planktonic food availability and suspension-feeder abundance: evidence of in situ depletion. J Exp Mar Biol Ecol 49:151-161

Button DK, Robertson B (2000) Properties of very small organisms. In: Size limits of very small organisms, Panel 2, proceedings of a workshop. Space Studies Bulletin, National Academy of Sciences, Washington, DC

Capone DG, Dunham SE, Horrigan SG, Duguay LE (1992) Microbial nitrogen transformations in unconsolidated coral reef sediments. Mar Ecol Prog Ser 80:75-88

Carlson CA, Ducklow HW (1996) Growth of bacterioplankton and consumption of dissolved organic carbon in the Sargasso Sea. Aquat Microb Ecol 10:69-85

Carlson GA, Giovannoni SJ, Hansell DA, Goldberg SJ, Parsons R, Otero MP, Vergin K, Wheeler BR (2002) Effect of nutrient amendments on bacterioplankton production, community structure, and DOC utilization in the northwestern Sargasso Sea. Aquat Microb Ecol 30:19-36

Cotner JB, Ammerman JW, Peele ER, Bentzen E (1997) Phosphorus limited bacterioplankton growth in the Sargasso Sea. Aquat Microb Ecol 13:141-149

Del Giorgio P, Cole JJ (1998) Bacterial growth efficiency in natural aquatic systems. Annu Rev Ecol Syst 29:503-541 
Ducklow HW, Mitchell R (1979) Bacterial populations and adaptations in the mucus layers on living corals. Limnol Oceanogr 24:715-725

Elser JJ, Stabler LB, Hassett RP (1995) Nutrient limitation of bacterial growth and rates of bacterivory in lakes and oceans: a comparative study. Aquat Microb Ecol 9:105-110

Fabricius KE, Dommisse M (2000) Depletion of suspended particulate matter over coastal reef communities dominated by zooxanthellate soft corals. Mar Ecol Prog Ser 196: $157-167$

Ferrier-Pagès C, Gattuso JP (1998) Biomass, production and grazing rates of pico- and nanoplankton in coral reef waters (Miyako Island, Japan). Microb Ecol 35:46-57

Ferrier-Pagès C, Leclercq N, Jaubert J, Pelegri SP (2000) Enhancement of pico- and nanoplankton growth by coral exudates. Aquat Microb Ecol 21:203-209

Fonnes Flaten GA, Castberg T, Tanaka T, Thingstad TF (2003) Interpretation of nutrient-enrichment bioassays looking at sub-populations in a marine bacterial community. Aquat Microb Ecol 33:11-18

Gast GJ, Wiegman S, Wieringa E, van Duyl FC, Bak RPM (1998) Bacteria in coral reef water types: removal of cells, stimulation of growth and mineralization. Mar Ecol Prog Ser 167:37-45

Gast GJ, Jonkers PJ, van Duyl FC, Bak RPM (1999) Bacteria, flagellates and nutrients in island fringing coral reef waters: influence of the ocean, the reef and eutrophication. Bull Mar Sci 65:523-538

Goldman JC, Dennett MR (1991) Ammonium regeneration and carbon utilization by marine bacteria grown on mixed substrates. Mar Biol 109:369-378

Goldman JC, Dennett MR (2000) Growth of marine bacteria in batch and continuous culture under carbon and nitrogen limitation. Limnol Oceanogr 45:789-800

Goldman JC, Caron DA, Dennett MR (1987) Regulation of gross growth efficiency and ammonium regeneration in bacteria by substrate $\mathrm{C}: \mathrm{N}$ ratio. Limnol Oceanogr 32: 1239-1252

Hatcher BG (1997) Organic production and decomposition. In: Birkeland C (ed) Life and death of coral reefs. Chapman \& Hall, New York, p 140-175

Heil CA, Chaston K, Jones A, Bird P, Longstaff B, Constanzo S, Dennison WC (2004) Benthic microalgae in coral reef sediments of the southern Great Barrier Reef, Australia. Coral Reefs 23:336-340

Herndl GJ (1993) Dialysis bag incubation as a nonradiolabeling technique to estimate bacterioplankton production in situ. In: Kemp PF, Sherr BF, Sherr EB, Cole JJ (eds) Handbook of methods in aquatic microbial ecology. Lewis Publishers, Boca Raton, FL, p 553-556

Hobbie JE, Daley RJ, Jasper S (1977) Use of nuclepore filters for counting bacteria by fluorescence microscopy. Appl Environ Microbiol 33:1225-1228

Kirchman DL (2000) Uptake and regeneration of inorganic nutrients by marine heterotrophic bacteria. In: Kirchman DL (ed) Microbial ecology of the oceans. Wiley-Liss, New York, p 261-288

Landry MR, Haas LW, Fagerness VL (1984) Dynamics of microbial plankton communities: experiments in Kaneohe Bay, Hawaii. Mar Ecol Prog Ser 16:127-133

Lee S, Fuhrman JA (1987) Relationships between biovolume and biomass of naturally derived marine bacterioplankton. Appl Environ Microbiol 53:1298-1303

Middelboe M, Hagström A, Blackburn N, Sinn B and 5 others (2001) Effects of bacteriophages on the population dynamics of four strains of pelagic marine bacteria. Microb Ecol 42:395-406
Moriarty DJW, Pollard PC, Hunt WG (1985) Temporal and spatial variation in bacterial production in the water column over a coral reef. Mar Biol 85:285-292

Moriarty DJW, Roberts DG, Pollard PC (1990) Primary and bacterial productivity of tropical seagrass communities in the Gulf of Carpentaria, Australia. Mar Ecol Prog Ser 61: $145-157$

Paul JH, DeFlaun M, Jeffrey WH (1986) Elevated levels of microbial activity in the coral surface microlayer. Mar Ecol Prog Ser 33:29-40

Pile AJ (1999) Resource partitioning by Caribbean coral reef sponges: is there enough food for everyone? Mem Queensl Mus 44:457-461

Pomeroy LR, Sheldon JE, Sheldon WM Jr, Peters F (1995) Limits to growth and respiration of bacterioplankton in the Gulf of Mexico. Mar Ecol Prog Ser 117:259-268

Rasheed M, Badran MI, Richter C, Huettel M (2002) Effect of reef framework and bottom sediment on nutrient enrichment in a coral reef of the Gulf of Aqaba, Red Sea. Mar Ecol Prog Ser 239:277-285

Richter C, Wunsch M, Rasheed M, Kötter I, Badran MI (2001) Endoscopic exploration of Red Sea coral reefs reveals dense populations of cavity-dwelling sponges. Nature 413:726-730

Sala MM, Peters F, Gasol JM, Pedros-Alio C, Marasse C, Vaque D (2002) Seasonal and spatial variations in the nutrient limitation of bacterioplankton growth in the northwestern Mediterranean. Aquat Microb Ecol 27: $47-56$

Scheffers SR, de Goeij J, van Duyl FC, Bak RPM (2003) The cave-profiler: a simple tool to describe the 3D structure of inaccessible coral reef cavities. Coral Reefs 22:49-53

Scheffers SR, Nieuwland G, Bak RPM, van Duyl FC (2004) Removal of bacteria and nutrient dynamics within the coral reef framework of Curaçao (Netherlands Antilles). Coral Reefs 23:413-422

Shiah FK, Kao SJ, Liu KK (1998) Bacterial production in the western Equatorial Pacific: implications of inorganic nutrient effects on dissolved organic carbon accumulation and consumption. Bull Mar Sci 62(3):795-808

Strom L (2000) Bacterivory: interactions between bacteria and their grazers. In: Kirchman DL (ed) Microbial ecology of the oceans, Vol 12. Wiley-VCH, Weinheim, p 351-386

Thingstad F (1987) Utilization of N, P and organic C by heterotrophic bacteria. I. Outline of a chemostat theory with a consistent concept of 'maintenance' metabolism. Mar Ecol Prog Ser 35:99-109

Thingstad TF, Rassoulzadegan F (1995) Nutrient limitations, microbial food webs, and 'biological C-pumps': suggested interactions in a P-limited Mediterranean. Mar Ecol Prog Ser 117:299-306

Thingstad TF, Zweifel UL, Rassoulzadegan F (1998) P limitation of heterotrophic bacteria and phytoplankton in the northwest Mediterranean. Limnol Oceanogr 43:88-94

Torréton JP, Talbot V, Garcia N (2000) Nutrient stimulation of bacterioplankton growth in Tuamotu atoll lagoons. Aquat Microb Ecol 21:125-137

Vadstein O, Jensen A, Olsen LM, Reinertsen HR (1988) Growth and phosphorus status of limnetic phytoplankton and bacteria. Limnol Oceanogr 33:489-503

Vadstein O, Olsen LM, Busch A, Andersen T, Reinertsen HR (2003) Is phosphorus limitation of heterotrophic bacteria and accumulation of degradable DOC a normal phenomenon in phosphorus limited systems? A microcosm study. FEMS Microbiol Ecol 46:307-316

van Duyl FC (1985) Atlas of the living reefs of Curaçao and Bonaire (Netherlands Antilles), Vol 117. Foundation for 
Scientific Research in Surinam and the Netherlands Antilles, Utrecht, p 1-63

van Duyl FC, Gast GJ (2001) Linkage of small-scale spatial variations in DOC, inorganic nutrients and bacterioplankton growth with different coral reef water types. Aquat Microb Ecol 24:17-26

van Duyl FC, Gast GJ, Steinhoff W, Kloff S, Veldhuis MJW, Bak RPM (2002) Factors influencing the short-term variation in phytoplankton composition and biomass in coral reef waters. Coral Reefs 21:293-306

van Duyl FC, Scheffers SR, Driscoll M, Thomas FIM (in press) The effect of water exchange on bacterioplankton deple-

Editorial responsibility: Otto Kinne (Editor-in-Chief), Oldendorf/Luhe, Germany tion and inorganic nutrient dynamics in coral reef cavities. Coral Reefs

Wilcox RM, Fuhrman JA (1994) Bacterial viruses in coastal seawater: lytic rather than lysogenic production. Mar Ecol Prog Ser 114:35-45

Wild C, Huettel M, Klueter A, Kremb SG, Rasheed MYM, Jørgensen BB (2004) Coral mucus functions as an energy carrier and particle trap in the reef ecosystem. Nature 428 : 66-70

Yahel G, Post AF, Fabricius KE, Marie D, Vaulot D, Genin A (1998) Phytoplankton distribution and grazing near coral reefs. Limnol Oceanogr 43:551-563

Submitted: November 9, 2004; Accepted: May 10, 2005

Proofs received from author(s): August 1, 2005 